\title{
Community Structure and Distribution Pattern of Intertidal Invertebrate Macrofauna at Some Anthropogenically Influenced Coasts of Kathiawar Peninsula (India)
}

\author{
Poonam Bhadja, ${ }^{1}$ Paresh Poriya, ${ }^{2}$ and Rahul Kundu ${ }^{2}$ \\ ${ }^{1}$ Gujarat Arts and Science College, Ellisbridge, Ahmedabad, Gujarat 380006, India \\ ${ }^{2}$ Department of Biosciences, Saurashtra University, Rajkot, Gujarat 360005, India \\ Correspondence should be addressed to Rahul Kundu; rskundu@sauuni.ernet.in
}

Received 28 April 2014; Revised 9 July 2014; Accepted 16 July 2014; Published 6 August 2014

Academic Editor: Calum MacNeil

Copyright (c) 2014 Poonam Bhadja et al. This is an open access article distributed under the Creative Commons Attribution License, which permits unrestricted use, distribution, and reproduction in any medium, provided the original work is properly cited.

\begin{abstract}
Present communication reports the community structure and distribution pattern of intertidal invertebrate macrofauna at four shores of the Kathiawar peninsular coastline off the Arabian Sea (India). The selected shores have different levels of human activities. Present report tests three hypotheses; that is, (i) distribution of invertebrate macrofauna in these shores is influenced by space and time, (ii) abiotic factors have a profound influence on the distribution pattern of intertidal macrofaunal assemblages, and (iii) human activities influence the community structure of the intertidal invertebrate macrofauna at these shores. To test these hypotheses, spatiotemporal variations in different ecological indices were studied. A total of 60 species from six phyla were considered for the study. High species diversity was recorded during winter and monsoon seasons in almost all the shores studied. It was also evident that a few environmental factors had a cumulative influence on the distribution pattern of intertidal macrofauna. Significant spatial variations in the species diversity and evenness were also observed. Though the shores studied have similar coast characteristics and climatic conditions, they face different levels of human activities. Therefore, the observed variations in the intertidal faunal assemblage were possibly caused by anthropogenic stress.
\end{abstract}

\section{Introduction}

Rocky shores are the most extensive littoral habitats exposed to eroding waves and, thus, are ecologically very important [1]. Among that, invertebrate communities of rocky shores function as integrators of ecological processes over time scale $[2,3]$. The communities act as a bioindicator and may be monitored to assess ecological change due to anthropogenic actions $[4,5]$. Anthropogenic stress is the response of biological entity, of any individual, population, or community, to an anthropogenic disturbance. This stress at one level of organization may also have an impact on another level. Since it is difficult to detect the effects of anthropogenic stress at the individual organismic level, they are more often investigated at a population or community level [1]. Pielou [6] and Magurran [7] reported that the measures of species diversity play a central role in ecology and conservation biology. Benthic habitat is complex and many of the environmental factors that influence macroinvertebrate assemblage structure are interrelated $[8,9]$; thus, identifying a single environmental factor as most important in structuring assemblages is challenging. Intertidal invertebrates and macroalgae occupy low trophic levels and are responding quicker to alterations in climate than species at higher trophic levels [10]. They often show the first response in a cascade of effects up the food chain and are therefore important sentinels of climate change impacts [11]. In addition to temperature, several other climate-related drivers are also impacting and have adverse effects upon coastal habitats including sea level rise, increases in relative wave height and storminess, and the associated secondary effects arising from adaptation and mitigation activities in coastal regions [12].

Macrobenthic invertebrates are useful bioindicators providing a more accurate understanding of changing aquatic 
conditions than chemical and microbiological data, which at least give short-term fluctuations $[4-9,13]$. Their composition, abundance, and distribution can be influenced by water quality $[14,15]$. They all stated that variations in the distribution of macrobenthic organisms could be a result of differences in the local environmental conditions [15]. However, the composition, abundance, and distribution of invertebrate macrofauna in the rocky intertidal zones are generally influenced by water quality $[5,16,17]$. Understanding the relative importance of environmental factors in structuring assemblages is important because benthic macroinvertebrates are used more than any other organisms to assess the condition of streams and identifying the factors primarily associated with altered macroinvertebrate assemblages is necessary before restoration action can begin.

The coastline of Kathiawar Peninsula is significantly rocky with irregular patches of sand or mud. Veraval and Mangrol are the two developed fishing ports with allied installations which handle $62 \%$ of fish catch for several export oriented fish processing units located in the vicinity. Apart from existing ports that facilitate import or export of fish and fishery products, this coastal area is also dominated by large industries like rayon, cement, food and fodder processing, fertilizers, salt, cement, soda ash, and lime stone associated industries. Tourism is also another related human activity which directly affects the intertidal zones of the Kathiawar Peninsula. Thus, studies on the current ecological status of the macrofaunal assemblage in this industrially significant coastline are very important from ecological and conservation points of view. Therefore, the present communication is relevant not only for this particular region but also for any other coastline with similar conditions.

The present communication reports the ecological status of various intertidal invertebrate faunal groups of the rocky and rocky-muddy intertidal areas at South Saurashtra coastline off the Arabian Sea. It also reports the community structure of the intertidal zones in relation to abiotic factors and anthropogenic activities. Present report tests the hypotheses that (i) there is a spatiotemporal influence on the distribution pattern of different invertebrate phyla at the selected shores along this continuous coastline, (ii) abiotic factors influence the intertidal macrofaunal assemblages of the shores that are on the open sea coastline, and (iii) human activities have a profound influence on the gross community structure of the intertidal faunal assemblages at these open sea shores.

\section{Materials and Methods}

2.1. Study Location. For this study, four sampling sites, namely, Dwarka $\left(22^{\circ} 13^{\prime} \mathrm{N}, 68^{\circ} 58^{\prime} \mathrm{E}\right)$, Mangrol $\left(21^{\circ} 07^{\prime} \mathrm{N}\right.$, $\left.70^{\circ} 07^{\prime} \mathrm{E}\right)$, Veraval $\left(20^{\circ} 53^{\prime} \mathrm{N}, 70^{\circ} 26^{\prime} \mathrm{E}\right)$, and Kodinar $\left(20^{\circ} 46^{\prime} \mathrm{N}\right.$, $70^{\circ} 46^{\prime} \mathrm{E}$ ) were selected (Figure 1). These sites were chosen on the basis of their strategic locations for industries and related infrastructural facilities and different anthropogenic activities along the entire coastal area. Dwarka is a major Hindu pilgrim town and a tourist place with low human activities on the coast. The intertidal belt of Dwarka consists of large rocks and boulders causing resistance to upcoming

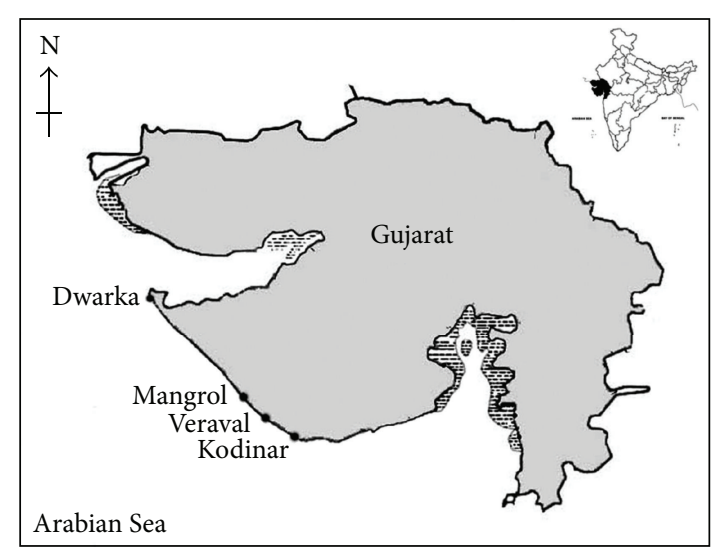

FIGURE 1: Map showing the study locations along the South Saurashtra coastline off the Arabian Sea.

wave and, hence, generates harsh water splash. Mangrol is a small hamlet with a fish landing jetty and few small scale fisheries related industries. This site is experiencing medium anthropogenic pressure on the coast. The entire intertidal belt of Mangrol is interspersed with numerous tide pools, puddles, crevices, and channels with intermittent sandy patches. On the other hand, Veraval is the largest fish landing site of India, surrounded by many fish processing plants and large industrial units. The substratum of the intertidal zones at Veraval is mainly rocky-sandy with few muddy patches. Kodinar is a small industrial town with large cement and sugar industries located near the coastline. The intertidal zone of Kodinar is made up of hard flat rocky substratum having small sized depressions interspersed with pools and puddles. Veraval and Kodinar shores are considered as high anthropogenic pressure zones.

2.2. Field Sampling. Studies on the macrofaunal diversity and seawater quality (in triplicate) from the intertidal regions of these sites were carried during November 2008 to October 2009. The entire intertidal belt of each sampling site was subdivided into three vertical zones. The macrofaunal diversity and distribution in the intertidal belt at each station were studied during the low tide by quadrat method [18]. Quadrat of $0.25 \mathrm{~m}^{2}$ was laid along the employed line transect at every $10 \mathrm{~m}$ interval on the intertidal region. A minimum of ten quadrates were laid in a criss-cross direction at the intertidal belt to cover the maximum exposed area. For water quality, previously published data of different seawater quality parameters were considered [17].

2.3. Data Analysis. Each study site was sampled monthly for quantitative analysis of intertidal macrofauna. The monthly data from the study sites were integrated as a seasonal dataset as the weather condition of this part of the peninsular India typically represents the periods of winter (December to February), summer (March to May), monsoon (June to August), and post-monsoon (September to November) seasons. Diversity of the macrofauna was determined using 


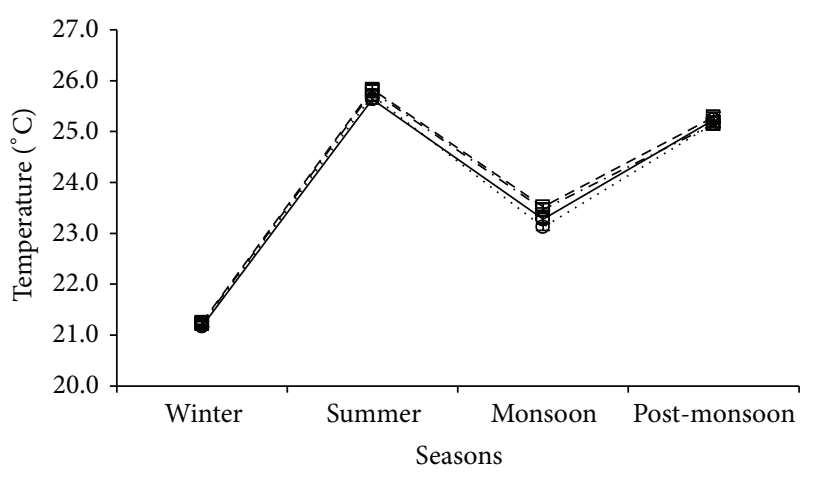

(a)

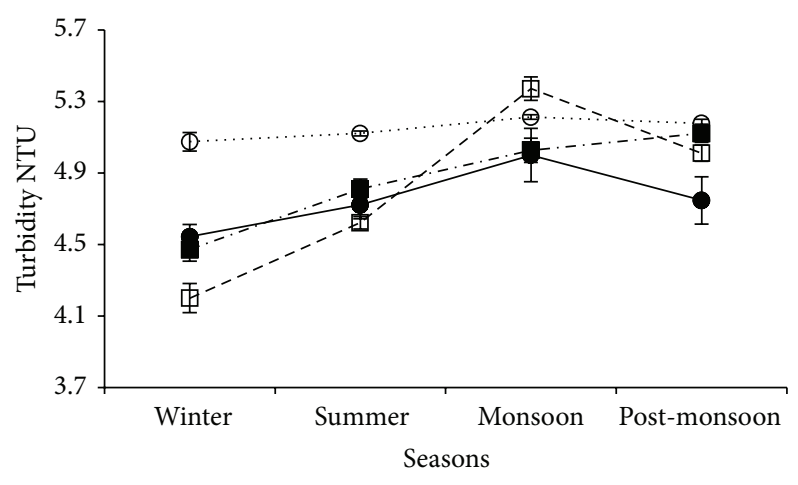

(c)

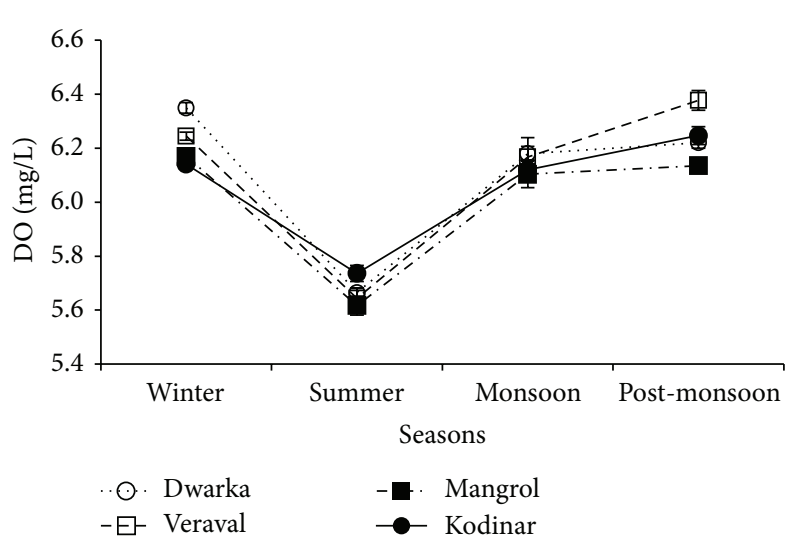

(e)

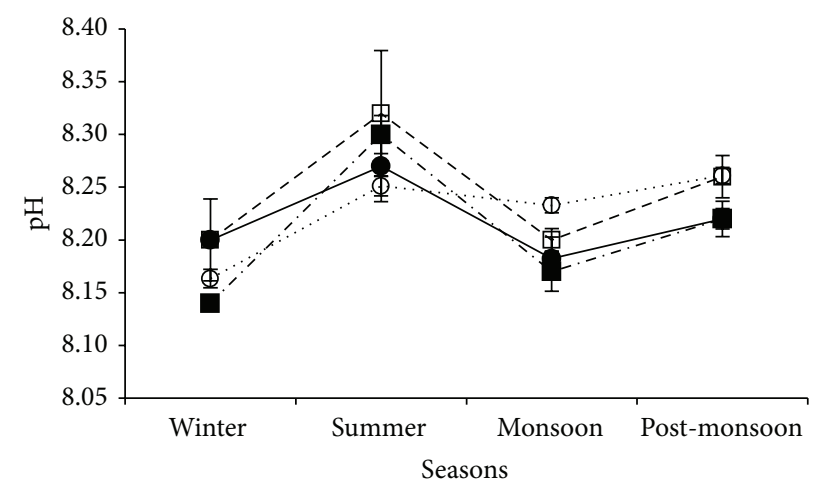

(b)

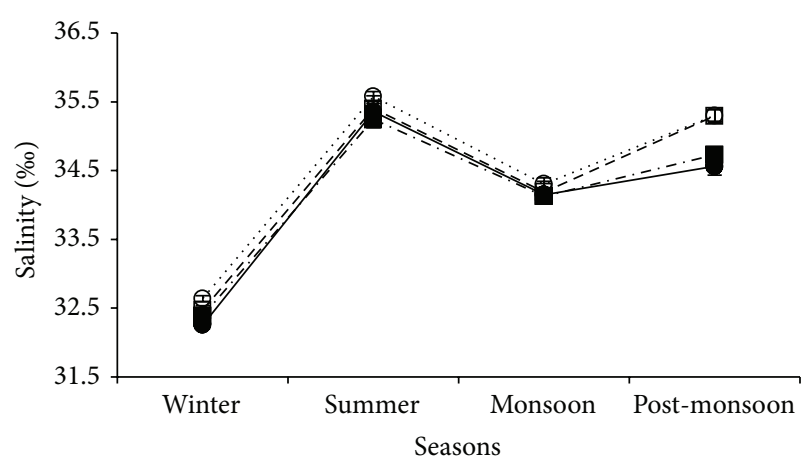

(d)

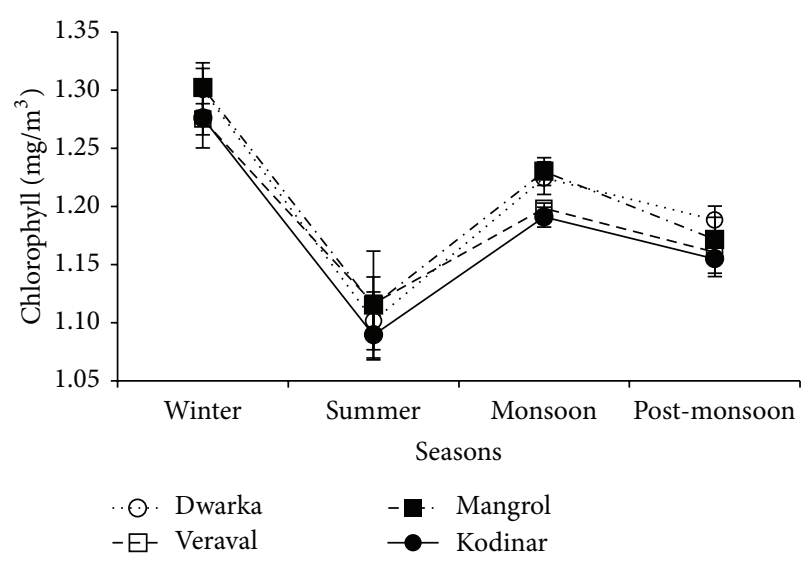

(f)

FIGURE 2: Seasonal variations in the seawater quality parameters of the coasts studied. Error bars represent standard deviation over mean values.

Shannon-Wiener index [19] and Pielou's index $(J)$ of evenness and Menhinick index $(d)$ of species richness was applied to calculate the diversity as per Odum [20]. The Shannon Index $\left(H^{\prime}\right)$ was calculated by the formula $H^{\prime}=-(\mathrm{Pi} \times \ln \mathrm{Pi})$, where $\mathrm{Pi}$ is the fraction of the $i$ th species of total fauna. Pielou's evenness $\left(J^{\prime}\right)$ was calculated by the formula $J^{\prime}=$ $H^{\prime} / \ln S$, where $H^{\prime}$ is the Shannon index as defined above and $S$ is the number of species observed. Species richness $(d)$ is based on the number of species present in a community $(S)$ and incorporates the total number of individuals in the community $(N)$. The species richness was calculated by the formula $d=S / \sqrt{N}$.

Two-factor analysis of variance (ANOVA) was employed to estimate the spatiotemporal variations in diversity, evenness, and richness values. Correlation coefficients analysis was also done to assess the influence of abiotic factors on the macrofaunal community structure [21]. Bray-Curtis similarity analysis was performed on the species diversity data to detect multivariate spatial similarities. All statistical analyses were done as per Sokal and Rohlf [22]. 

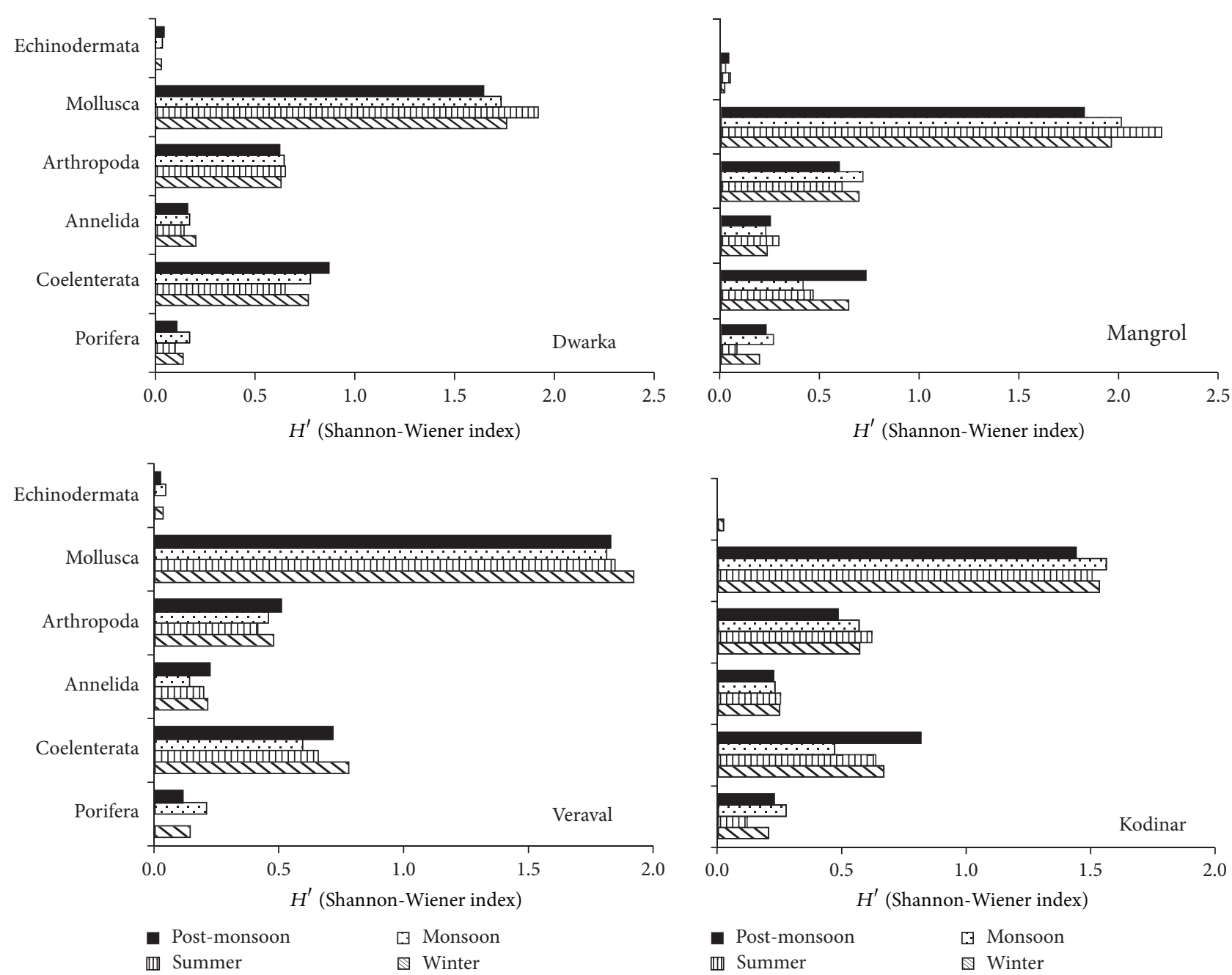

Figure 3: Seasonal variations in the Shannon-Wiener diversity $\left(H^{\prime}\right)$ of major intertidal phyla from all three littoral zones. Note the change of scale in different coasts studied.

\section{Results}

3.1. Abiotic Factors. Seasonal changes in various physicochemical parameters of seawater at the four selected locations are shown in Figure 2. Regarding the measures taken for the environmental parameters, it was observed that amongst the abiotic factors, highest mean water temperature was recorded during summer at all the coasts studied (Figure 2(a)). The $\mathrm{pH}$ value showed a similar trend and was found low during the monsoon (Figure 2(b)). The salinity was found to be high during summer and low during the winter at almost all the sampling sites (Figure 2(d)). Dissolved oxygen level was high during the post-monsoon season $(6.14$ to $6.38 \mathrm{mg} / \mathrm{L})$ at almost all the sampling sites. Relatively lower dissolved oxygen level was observed during winter than the post-monsoon (Figure 2(e)). The seawater turbidity was relatively constant during monsoon to post-monsoon, ranging from 4.5 to 5.1 NTU at all the sampling sites (Figure 2(c)). High chlorophyll level was observed during winter which decreased to the minimum during summer (Figure 2(f)).
3.2. Macrofaunal Community Structure. In the present study a total of 60 different invertebrate macrofaunal species were identified from the intertidal regions of the sampling sites. These species belonged to different groups like 3 species of Porifera, 8 species of Coelenterata, 5 species of Annelida, 6 species of Arthropoda, 35 species of Mollusca, and 3 species of Echinodermata. Molluscan forms were the most common and dominant species followed by Coelenterate, Arthropoda, and Annelida at all the sampling stations (Figure 6). The levels of diversity, richness, and evenness indices of all these invertebrate groups were analyzed and given in Figures 3-5. Diversity (Shannon-Wiener index [19]) values ranged from 0.01 during winter to 2.09 during summer at Mangrol. The value of diversity indices of phylum Porifera varied from 0.07 to 0.27 during summer and monsoon seasons at Mangrol and Kodinar, respectively. In general, the species diversity of phylum Coelenterata was comparatively low at almost all the sampling sites. However, it showed moderate diversity values at Dwarka during monsoon season. Highest species diversity of this group was recorded at Veraval during winter 

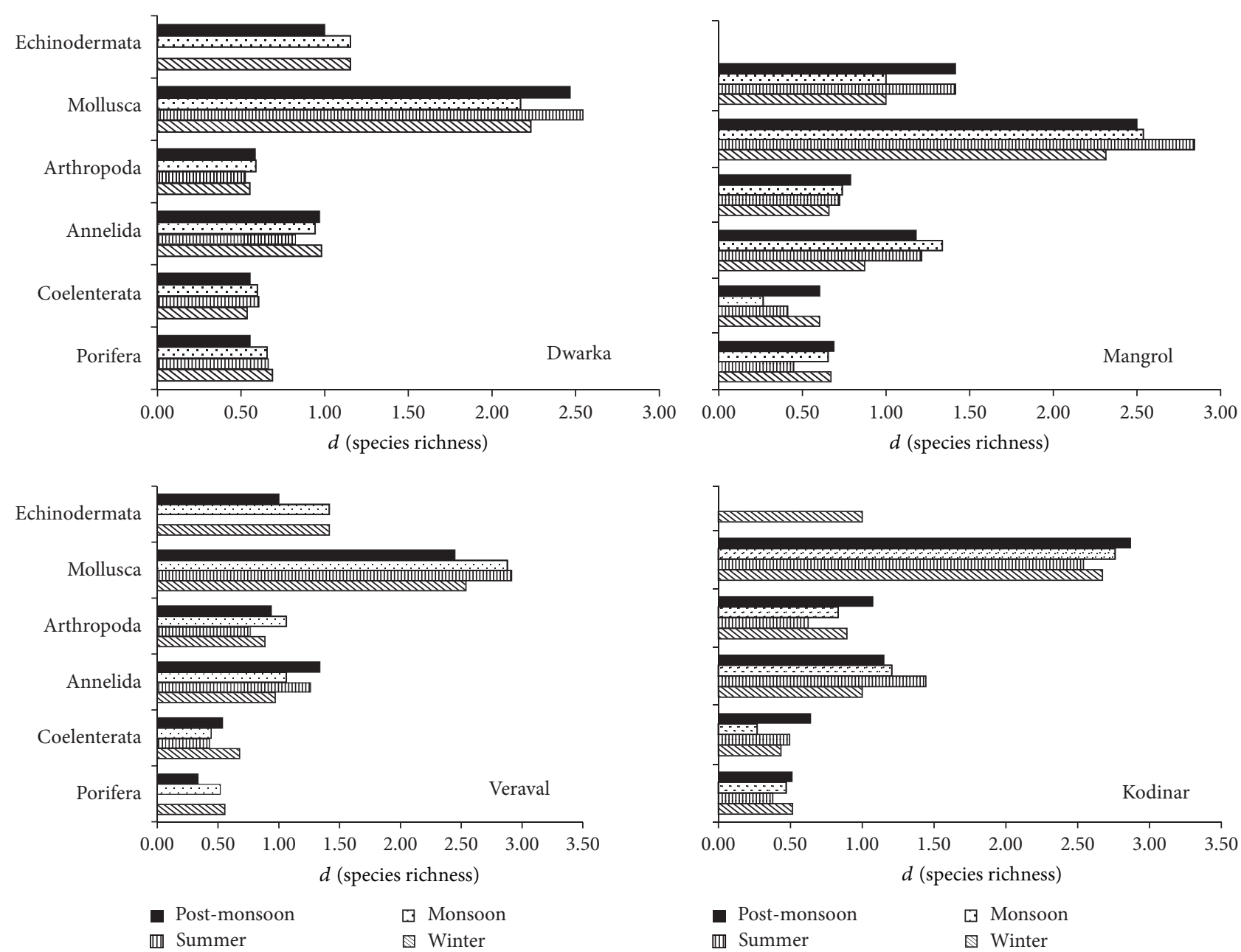

FIGURE 4: Seasonal variations in the species richness $(d)$ of major intertidal phyla from all three littoral zones.

season (Figure 3). Shannon $H^{\prime}$ values were high at Mangrol and Dwarka during winter and summer seasons, but were found to be low at other locations. Significant temporal variations in the total species diversity were observed in three groups (phyla Annelida, Arthropoda, and Mollusca) (Table 1). The total diversity of phylum Echinodermata did not show any significant variations possibly due to the fact that these animals generally prefer the lower littoral zone which is comparatively less affected by the changing environmental factors. Similarly, Porifera and Arthropoda also showed significant temporal variations in species richness (Table 1). However, when the diversity values of all macrofauna from all phyla are pooled together, significant spatial variations are shown. The observed spatial variations in the species evenness $\left(J^{\prime}\right)$ were found to be more during the post-monsoon followed by the monsoon and winter seasons (Figure 5). The minimum evenness was observed in Echinodermata during winter and maximum evenness was in Coelenterata during monsoon season. Though high species richness was observed in echinoderms, its evenness was the lowest amongst all groups studied (Figures 4 and 5). High species richness and evenness were observed in Mollusca followed by annelids, sponges, and arthropods (Figures 4 and 5). Results of the two-factor ANOVA showed significant temporal variations in species richness of Porifera and Arthropoda (Table 1). Similarly, spatiotemporal variations in the species evenness were observed only in phylum Mollusca, whereas only temporal variations were observed in case of phylum Arthropoda (Table 1). Similar results were also observed in the dendrogram showing the similarity in the macrofaunal diversity of all species combined between the selected shores (Figure 7).

\section{Discussion}

Anthropogenic disturbances can affect the physiological state of the animals, which may result in changes of processes, such as rates of growth $[23,24]$, and disturbances affect recruitment $[25,26]$ or mortality $[25,27]$ and, therefore, are most easily identified as differences in the numbers and types of animals found in disturbed or undisturbed sites [28-30]. In the long history of the marine biological 

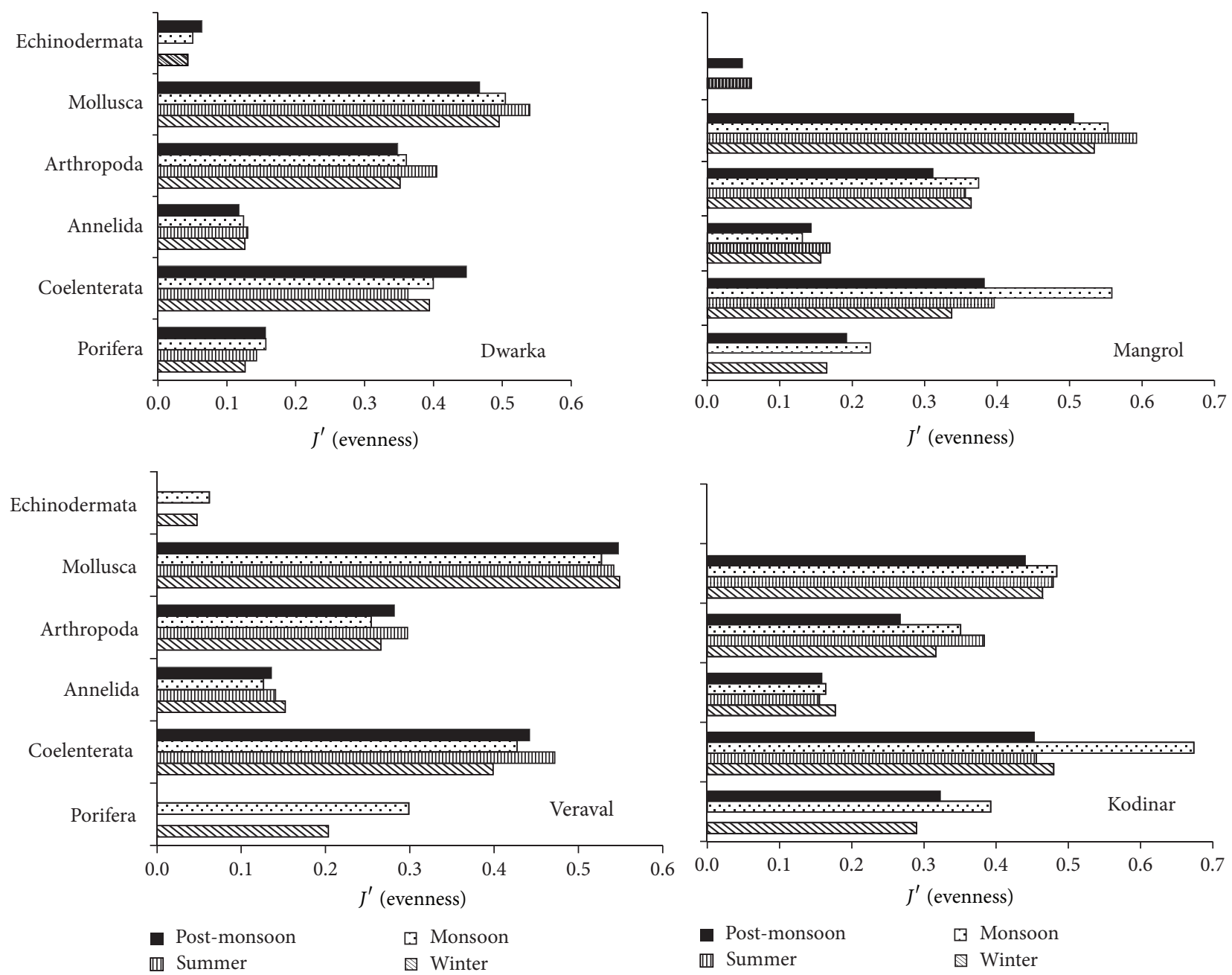

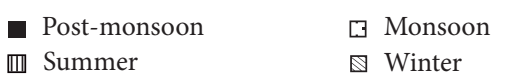

FIGURE 5: Seasonal variations in the species evenness $\left(J^{\prime}\right)$ of major intertidal phyla from all three littoral zones.

TABLE 1: Results of the two-way ANOVA (without replication) of the mean seasonal Shannon-Wiener diversity $\left(H^{\prime}\right)$, richness $(d)$, and evenness $\left(J^{\prime}\right)$ values of the six invertebrate phyla sampled at the four stations.

\begin{tabular}{|c|c|c|c|c|}
\hline \multirow{2}{*}{ Animal group } & \multirow{2}{*}{ Source of variation } & \multicolumn{3}{|c|}{$F$ values } \\
\hline & & $H^{\prime}$ & $d$ & $J^{\prime}$ \\
\hline \multirow{2}{*}{ Porifera } & Station & $18.32^{*}$ & 3.09 & $4.55^{*}$ \\
\hline & Season & $7.91^{*}$ & $5.25^{*}$ & 1.57 \\
\hline \multirow{2}{*}{ Coelenterata } & Station & $7.65^{*}$ & 2.52 & 2.30 \\
\hline & Season & $7.71^{*}$ & 0.93 & 2.40 \\
\hline \multirow{2}{*}{ Annelida } & Station & 1.17 & 2.11 & 2.89 \\
\hline & Season & $6.08^{*}$ & 2.82 & $13.11^{*}$ \\
\hline \multirow{2}{*}{ Arthropoda } & Station & 0.72 & 2.95 & 3.65 \\
\hline & Season & $11.30^{*}$ & $10.90^{*}$ & $10.14^{*}$ \\
\hline \multirow{2}{*}{ Mollusca } & Station & 3.49 & 1.36 & $4.17^{*}$ \\
\hline & Season & $18.67^{*}$ & 3.12 & $14.83^{*}$ \\
\hline \multirow{2}{*}{ Echinodermata } & Station & 0.75 & 2.09 & 0.17 \\
\hline & Season & 1.73 & 3.15 & 1.25 \\
\hline
\end{tabular}

${ }^{*}$ Significant at $P=0.05$ level; tabulated $F$ value at $\mathrm{df} 15=3.86$. 

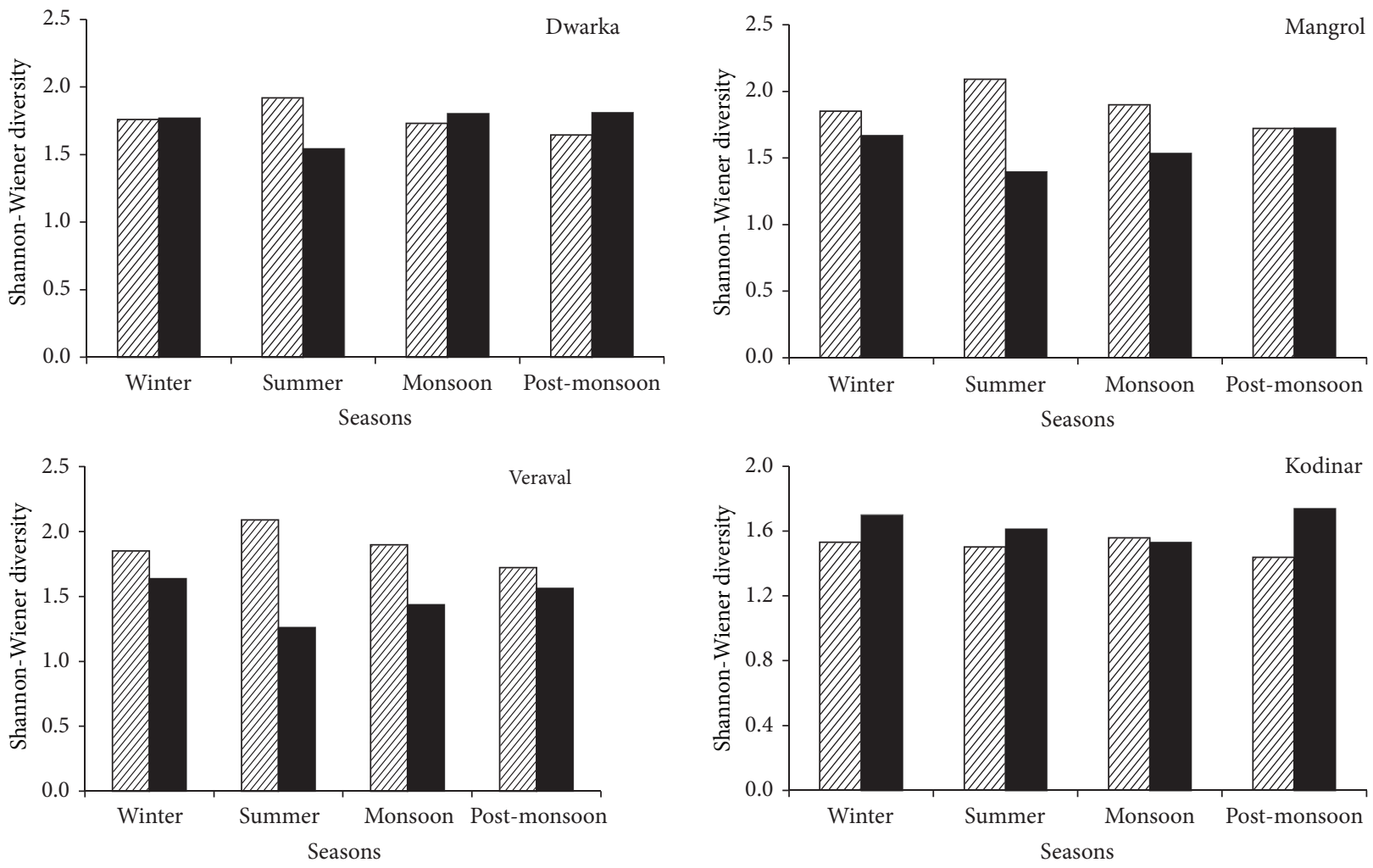

$\square$ Mollusca
Other than mollusca

ఐ Mollusca

- Other than mollusca

FIGURE 6: Comparative histograms showing Shannon-Wiener diversity $\left(H^{\prime}\right)$ values between phylum Mollusca and all other phyla pooled together.

TABLE 2: Results of single factor ANOVA for the Shannon diversity $\left(H^{\prime}\right)$, richness $(d)$, and evenness $\left(J^{\prime}\right)$ of major macrofaunal phyla at four shores studied.

\begin{tabular}{lccr}
\hline & & \multicolumn{2}{c}{$F$ values } \\
& $H^{\prime}$ & $d$ & $J^{\prime}$ \\
\hline Porifera & 1.4851 & 3.4466 & 0.8312 \\
Coelenterata & 2.8945 & 0.6714 & 1.8127 \\
Annelida & $5.8276^{*}$ & 2.2063 & $8.8955^{*}$ \\
Arthropoda & $12.1567^{*}$ & $7.3309^{*}$ & $6.0997^{*}$ \\
Mollusca & $11.5069^{*}$ & 2.8561 & $8.2687^{*}$ \\
Echinodermata & 1.8437 & 2.4773 & 1.5767 \\
Total & $\mathbf{8 . 9 9 2 4}^{*}$ & $\mathbf{1 . 9 8 2 7}$ & $\mathbf{1 . 0 6 1 3}$ \\
\hline
\end{tabular}

${ }^{*}$ Significant at $P=0.05$ level; tabulated $F$ value $=3.49$.

research, together with habitat structure, food availability, and predation, physicochemical parameters like temperature, $\mathrm{pH}$, conductivity, BOD, COD, and so forth are determining factors in structuring different marine assemblages [31-34]. The environmental factors, as the highest surface water temperature was recorded during summer, are influenced by the intensity of solar radiation, evaporation, freshwater influx, and cooling; summer peaks and monsoon troughs in air and water temperature were found similar to reported values for west coast of India by Arthur [35]. The low pH value during the monsoon was probably due to the cumulative influence of freshwater influx, dilution of saline water with rain, and reduction of salinity and temperature. Seasonal variations in the salinity observed in the present study influenced the fauna and, thus, were the limiting factor for the distribution of living organisms in the intertidal region [36-38]. Higher dissolved oxygen level might be due to the rough 


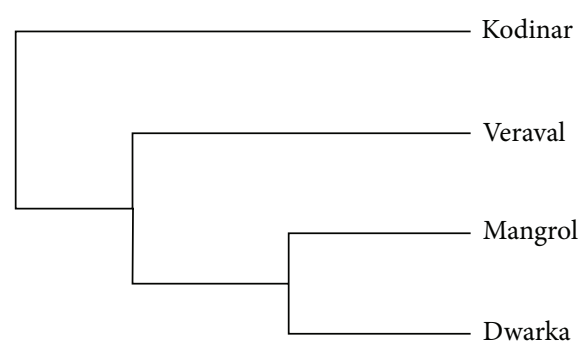

93 100

Similarity (\%)

FIgURE 7: Dendrogram showing similarity in the macrofaunal diversity of all species combined between the selected shores.

weather conditions during monsoon season $[39,40]$; however, lower dissolved oxygen level observed during winter is typical for the coastline studied [5, 17, 41]. The seawater turbidity was constant during monsoon possibly due to the mixing of rainwater runoff with seawater during monsoon season prevailing in this area [42]. High turbidity might have affected the species composition and community structure of marine macrobenthos in the intertidal region [42]. The trend of higher chlorophyll level was possibly in association with the northern Arabian Sea winter cooling phenomena $[17,43,44]$.

The results indicated that wide substratum preference, adaptational capabilities against changing environmental conditions and mobility to avoid harsh conditions have played possible roles [42]. The results of the two-factor ANOVA showed that only two faunal groups (Porifera and Coelenterata) showed spatiotemporal variations in the total diversity (Table 1) possibly due to fluctuations in the environmental factors and changing anthropogenic pressure. Khan et al. [45] reported higher Shannon diversity index, in the range of 2.5-3.5, as a healthy condition for this coastline. In the present study, the diversity indices were comparatively low at Veraval and Kodinar during the study period possibly due to the fluctuations in the environmental conditions and high human interference in the coastal area. It is possible that being predominantly rocky, the selected coasts harbor more species of the dominant phyla having moderate to high level of species richness typical for rocky intertidal assemblage [46]. Results of the present investigation showed high species richness and low species evenness in almost all the selected sampling sites. However, the observed low species evenness (Figure 5) was possibly due to the flatness of the intertidal areas exposed during low tide [41]. It is apparent from the present study (Table 2) that the species richness and evenness were influenced by environmental factors and were inversely correlated with anthropogenic disturbances [5]. High species richness recorded during the winter season at some of the study sites might be due to stable environmental factors that play an important role in faunal distribution [47-49].

The correlation coefficient analysis between the species richness and abiotic factors showed variations amongst different groups as well as within different parameters. Significant variations in the species richness of annelids with salinity were observed at Veraval and Kodinar $(r=$ 0.96 and 0.94 , resp.) possibly due to influx of freshwater runoff in these shores during monsoon. Molluscan forms and sponges were correlated with variations in $\mathrm{DO}$ at Mangrol $(r=0.97$ and 0.99 , resp. $)$ and Kodinar $(r=0.95$ and 0.98 , resp.). Variations in the salinity, dissolved oxygen, and turbidity were reported to affect the near shore environment [50-54]. The variations in the abiotic factors and human interference, thus, lead to the presence of a diverse range of habitats in these waters which are often characterized by distinct faunal assemblages [55-59]. Ingram and Lin [53] reported that species diversity directly correlates with the concentration of chlorophyll. In this study, Annelida were found to be associated with different levels of chlorophyll at Dwarka, Veraval, and Kodinar $(r=0.92,0.92$, and 0.96 , resp.). In case of species evenness, the macrofaunal groups were clearly influenced by few abiotic factors. In the present study, high correlation coefficient was observed in case of sponges at Veraval $(r=0.93)$ and Kodinar $(r=$ 0.97), possibly due to the industrial effluents and sewage disposal, which might have influenced the $\mathrm{pH}$ level of the area under study. Similar observations were evident in case of Coelenterata $(r=0.96)$ and Arthropoda $(r=0.97)$ at Veraval and Echinodermata $(r=0.96)$ at Mangrol. There was a significant positive correlation between the dissolved oxygen level and species richness of sponges at Mangrol $(r=$ $0.96)$ and Kodinar $(r=0.96)$ and, in case of Arthropoda, at Dwarka $(r=0.98)$ and Kodinar $(r=0.93)$. The results of the correlation coefficient clearly indicated that the species richness and evenness were lowest at sites that also had the highest anthropogenic activities [41]. Amongst the four coasts studied, Veraval and Kodinar were highly influenced by anthropogenic pressure, whereas, in Dwarka and Mangrol, the human influence was less (Figure 7) $[17,60-62]$.

\section{Conclusions}

Results of the present study indicated that there were no significant spatial variations in the species diversity of major macrofaunal phyla. This is possibly due to the fact that the shores studied are situated along the same continuous coastline and share common coast characteristics. Significant temporal variations in the faunal diversity of few phyla were observed indicating that the varying environmental factors do have a cumulative influence on the distribution pattern of the benthic organisms. Interestingly, significant variations in the species diversity, richness, and evenness were observed in Veraval and Kodinar where the coast characteristics and climatic conditions were almost identical. Therefore, it may be possible that though the selected four shores share similar coast characteristics and climatic conditions, the variations in the intertidal assemblage were influenced by human activities. It appears that Veraval and Kodinar coasts were highly affected by the anthropogenic pressure followed by Mangrol and Dwarka coasts, where the human 
influences on the intertidal were minimum. Appropriate conservational strategies should be taken to minimize the anthropogenic pressure on the affected coastal areas to maintain the rich and diverse rocky intertidal biota of this region.

\section{Conflict of Interests}

The authors declare that there is no conflict of interests regarding the publication of this paper.

\section{Acknowledgments}

The authors are thankful to the UGC, Government of India (DSA/CAS Programme), and Government of Gujarat (India) for support through a Research Oriented Programme in Marine Biology. The senior author is thankful to UGC, Government of India for a Meritorious Research Fellowship. One of the authors (Paresh Poriya) is thankful to Government of Gujarat (India) supported Major Research Oriented Programme in Marine Biology. Various related government agencies and nongovernmental organizations are also acknowledged for extending their support and active help during the study.

\section{References}

[1] T. P. Crowe, R. C. Thompson, S. Bray, and S. J. Hawkins, "Impacts of anthropogenic stress on rocky intertidal communities," Journal of Aquatic Ecosystem Stress and Recovery, vol. 7, no. 4, pp. 273-297, 2000.

[2] I. Kröncke, J. W. Dippner, H. Heyen, and B. Zeiss, "Longterm changes in macrofaunal communities off Norderney (East Frisia, Germany) in relation to climate variability," Marine Ecology Progress Series, vol. 167, pp. 25-36, 1998.

[3] F. Beuchel, B. Gulliksen, and M. L. Carroll, "Long-term patterns of rocky bottom macrobenthic community structure in an Arctic fjord (Kongsfjorden, Svalbard) in relation to climate variability (1980-2003)," Journal of Marine Systems, vol. 63, no. 1-2, pp. 35-48, 2006.

[4] R. B. Ikomi, F. O. Arimoro, and O. K. Odihirin, "Composition, distribution and abundance of macroinvertebrates of the upper reaches of River Ethiope Delta State, Nigeria," The Zoologist, vol. 3, pp. 68-81, 2005.

[5] A. Vaghela, P. Bhadja, J. Ramoliya, N. Patel, and R. Kundu, "Seasonal variations in the water quality, diversity and population ecology of intertidal macrofauna at an industrially influenced coast," Water Science and Technology, vol. 61, no. 6, pp. 15051514, 2010.

[6] E. C. Pielou, Ecological Diversity, Wiley-Interscience, New York, NY, USA, 1975.

[7] A. E. Magurran, Ecological Diversity and Its Measurement, Croom Helm Ltd., London, UK, 1988.

[8] C. F. Rabeni and G. W. Minshall, "Factors affecting microdistribution of stream benthic insects," Oikos, vol. 29, pp. 33-43, 1977.

[9] J. S. Gray, "The measurement of marine species diversity, with an application to the benthic fauna of the Norwegian continental shelf," Journal of Experimental Marine Biology and Ecology, vol. 250, no. 1-2, pp. 23-49, 2000.
[10] S. Jenouvrier, C. Barbraud, and H. Weimerskirch, "Effects of climate variability on the temporal population dynamics of southern fulmars," Journal of Animal Ecology, vol. 72, no. 4, pp. 576-587, 2003.

[11] C. R. Johnson, S. C. Banks, N. S. Barrett et al., "Climate change cascades: shifts in oceanography, species' ranges and subtidal marine community dynamics in eastern Tasmania," Journal of Experimental Marine Biology and Ecology, vol. 400, no. 1-2, pp. $17-32,2011$

[12] N. Mieszkowska, L. Firth, and M. Bentley, "Impacts of climate change on intertidal habitat," Marine Climate Change Impacts Partnership: Science Review, vol. 4, pp. 180-192, 2013.

[13] O. Ravera, "Utility and limits of biological and chemical monitoring of the aquatic environment," Annali di Chimica, vol. 88, no. 11-12, pp. 909-913, 1998.

[14] APHA, AWWA, and WEF, Standard Methods for the Examination of Water and Wastewater, American Public Health Association, Washington, DC, USA, 19th edition, 1995.

[15] W. O. Odiete, Environmental Physiology of Animals and Pollution, Diversified Resources, Lagos, Nigeria, 1999.

[16] A. D. I. George, J. F. N. Abowei, and J. F. Alfred-Ockiya, "The distribution, abundance and seasonality of benthic macro invertebrate in Okpoka creek sediments, Niger Delta, Nigeria," Research Journal of Applied Sciences, Engineering and Technology, vol. 2, no. 1, pp. 11-18, 2010.

[17] P. Bhadja and R. Kundu, "Status of the seawater quality at few industrially important coasts of Gujarat (India) off Arabian Sea," Indian Journal of Marine Sciences, vol. 41, no. 1, pp. 954-961, 2012.

[18] R. Misra, Ecology Work Book, Oxford and IBH Publishing, Calcutta, India, 1968.

[19] C. E. Shannon and W. Weaver, The Mathematical Theory of Communication, University of Illinois Press, Urbana, Ill, USA, 1963.

[20] E. P. Odum, Fundamentals of Ecology, WB Saunders, Philadelphia, Pa, USA, 3rd edition, 1971.

[21] T. R. E. Southwood, Ecological Methods, Chapman \& Hall, London, UK, 1978.

[22] R. R. Sokal and F. J. Rohlf, Biometry, W. H. Freeman, San Francisco, Calif, USA, 1969.

[23] A. Tablado, J. J. Lopez Gappa, and N. H. Magaldi, "Growth of the pulmonate limpet Siphonaria lessoni (Blainville) in a rocky intertidal area affected by sewage pollution," Journal of Experimental Marine Biology and Ecology, vol. 175, no. 2, pp. 211-226, 1994.

[24] T. Y. T. Ng and M. J. Keough, "Delayed effects of larval exposure to $\mathrm{Cu}$ in the bryozoan Watersipora subtorquata," Marine Ecology Progress Series, vol. 257, pp. 77-85, 2003.

[25] E. L. Johnston and M. J. Keough, "Field assessment of effects of timing and frequency of copper pulses on settlement of sessile marine invertebrates," Marine Biology, vol. 137, no. 5-6, pp. 10171029, 2000.

[26] E. L. Johnston and M. J. Keough, "Direct and indirect effects of repeated pollution events on marine hard-substrate assemblages," Ecological Applications, vol. 12, no. 4, pp. 1212-1228, 2002.

[27] G. W. Bryan, P. E. Gibbs, L. G. Hummerstone, and G. R. Burt, "The decline of the gastropod Nucella lapillus around south-west England: evidence for the effect of tributylin from antifouling paints.," Journal of the Marine Biological Association of the United Kingdom, vol. 66, no. 3, pp. 611-640, 1986. 
[28] S. D. A. Smith, "Impact of domestic sewage effluent versus natural background variability: an example from Jervis Bay, New South Wales," Australian Journal of Marine \& Freshwater Research, vol. 45, no. 6, pp. 1045-1064, 1994.

[29] S. D. A. Smith, "The macrofaunal community of Ecklonia radiata holdfasts: variation associated with sediment regime, sponge cover and depth," Australian Journal of Ecology, vol. 21, no. 3, pp. 144-153, 1996.

[30] M. G. Chapman, A. J. Underwood, and G. A. Skilleter, "Variability at different spatial scales between a subtidal assemblage exposed to the discharge of sewage and two control assemblages," Journal of Experimental Marine Biology and Ecology, vol. 189, no. 1-2, pp. 103-122, 1995.

[31] W. K. Dodds, "Community interactions between the filamentous alga Cladophora glomerata (L.) Kuetzing, its epiphytes, and epiphyte grazers," Oecologia, vol. 85, no. 4, pp. 572-580, 1991.

[32] M. J. Gibbons, "The impact of sediment accumulations, relative habitat complexity and elevation on rocky shore meiofauna," Journal of Experimental Marine Biology and Ecology, vol. 122, no. 3, pp. 225-241, 1988.

[33] J. E. Duffy and M. E. Hay, "Food and shelter as determinants of food choice by an herbivorous marine amphipod," Ecology, vol. 72, no. 4, pp. 1286-1298, 1991.

[34] P. Dauby, Y. Scailteur, and C. De Broyer, "Trophic diversity within the Eastern Weddell Sea amphipod community," Hydrobiologia, vol. 443, pp. 69-86, 2001.

[35] R. Arthur, "Coral bleaching and mortality in three Indian reef regions during an El Niño southern oscillation event," Current Science, vol. 79, no. 12, pp. 1723-1729, 2000.

[36] R. N. Gibson, "Recent studies on the biology of intertidal fishes," Oceanography and Marine Biology: An Annual Review, vol. 20, pp. 363-414, 1982.

[37] R. Balasubramanian and L. Kannan, "Physico-chemical characteristics of the coral reef environs of the Gulf of Mannar biosphere reserve, India," International Journal of Ecology and Environmental Sciences, vol. 31, no. 3, pp. 265-271, 2005.

[38] R. Sridhar, T. Thangaradjou, S. Senthil Kumar, and L. Kannan, "Water quality and phytoplankton characteristics in the Palk Bay, southeast coast of India," Journal of Environmental Biology, vol. 27 , no. 3, pp. 561-566, 2006.

[39] H. M. Faragallah, A. I. Askar, M. A. Okbah, and H. M. Moustafa, "Physico-chemical characteristics of the open Mediterranean Sea water for about $60 \mathrm{~km}$ from Damietta harbor, Egypt," Journal of Ecology and the Natural Environment, vol. 1, no. 5, pp. 106-119, 2009.

[40] S. Kundu, N. Mondal, P. S. Lyla, and S. Ajmal Khan, "Biodiversity and seasonal variation of macro-benthic infaunal community in the inshore waters of Parangipettai Coast," Environmental Monitoring and Assessment, vol. 163, no. 1-4, pp. 67-79, 2010.

[41] S. N. De Souza and R. Sen Gupta, "Variations of dissolved oxygen in Mandovi and Zuari estuaries," Indian Journal of Marine Science, vol. 15, pp. 67-71, 1986.

[42] S. Misra and R. Kundu, "Seasonal variations in population dynamics of key intertidal molluscs at two contrasting locations," Aquatic Ecology, vol. 39, no. 3, pp. 315-324, 2005.

[43] C. Raghunathan, A. Tewari, H. V. Joshi, V. G. S. Kumar, R. H. Trivedi, and Y. Khambhaty, "Impact of turbidity on intertidal macrofauna at Gopnath, Mahuva and Veraval coasts (west coast of India)," Indian Journal of Marine Sciences, vol. 32, no. 3, pp. 214-221, 2003.
[44] S. Dey and R. P. Singh, "Comparison of chlorophyll distributions in the northeastern Arabian Sea and southern Bay of Bengal using IRS-P4 Ocean Color Monitor data," Remote Sensing of Environment, vol. 85, no. 4, pp. 424-428, 2003.

[45] S. A. Khan, P. Murugesan, P. S. Lyla, and S. Jaganathan, "A new indicator macro invertebrate of pollution and utility of graphical tools and diversity indices in pollution monitoring studies," Current Science, vol. 87, no. 11, pp. 1508-1510, 2004.

[46] A. J. Underwood, "Experimental ecology of rocky intertidal habitats: what are we learning?" Journal of Experimental Marine Biology and Ecology, vol. 250, no. 1-2, pp. 51-76, 2000.

[47] Z. A. Ansari, B. S. Ingole, G. Banerjee, and A. H. Parulekar, "Spatial and temporal changes in benthic macrofauna from Mandovi and Zuari estuaries of Goa, West coast of India," Indian Journal of Marine Science, vol. 15, pp. 223-229, 1986.

[48] R. S. Kumar, "Macrobenthos in the mangrove ecosystem of Cochin backwaters, Kerala (southwest coast of India)," Indian Journal of Marine Sciences, vol. 24, no. 2, pp. 56-61, 1995.

[49] R. Sunil Kumar, "Intertidal zonation and seasonality of benthos in a tropical mangrove," International Journal of Ecology and Environmental Sciences, vol. 27, no. 3-4, pp. 199-208, 2001.

[50] F. Baldó, J. A. Cuesta, C. Fernández-Delgado, and P. Drake, "Effect of the regulation of freshwater inflow on the physicalchemical characteristics of water and on the aquatic macrofauna in the Guadalquivir estuary," Ciencias Marinas, vol. 31, no. 3, pp. 467-476, 2006.

[51] B. M. Gillanders and M. J. Kingsford, "Impacts of changes in flow of freshwater on estuarine and open coastal habitats and the associated organisms," Oceanography and Marine Biology: An Annual Review, vol. 20, pp. 233-309, 2002.

[52] M. Incera, S. P. Cividanes, M. Lastra, and J. López, “Temporal and spatial variability of sedimentary organic matter in sandy beaches on the northwest coast of the Iberian Peninsula," Estuarine, Coastal and Shelf Science, vol. 58, pp. 55-61, 2003.

[53] B. L. Ingram and J. C. Lin, "Geochemical tracers of sediment sources to San Francisco Bay," Geology, vol. 30, pp. 575-578, 2002.

[54] M. O. Tanaka and F. P. P. Leite, "Spatial scaling in the distribution of macrofauna associated with Sargassum stenophyllum (Mertens) Martius: analyses of faunal groups, gammarid life habits, and assemblage structure," Journal of Experimental Marine Biology and Ecology, vol. 293, no. 1, pp. 1-22, 2003.

[55] P. R. Teske and T. H. Wooldridge, "What limits the distribution of subtidal macrobenthos in permanently open and temporarily open/closed South African estuaries? Salinity vs. sediment particle size," Estuarine, Coastal and Shelf Science, vol. 57, no. 1-2, pp. 225-238, 2003.

[56] M. D. Wildsmith, I. C. Potter, F. J. Valesini, and M. E. Platell, “Do the assemblages of benthic macroinvertebrates in nearshore waters of Western Australia vary among habitat types, zones and seasons?" Journal of the Marine Biological Association of the United Kingdom, vol. 85, no. 2, pp. 217-232, 2005.

[57] T. Lasiak, "The putative impact of exploitation on rocky infratidal macrofaunal assemblages: a multiple-area comparison," Journal of the Marine Biological Association of the United Kingdom, vol. 79, no. 1, pp. 23-34, 1999.

[58] T. Lasiak, "The susceptibility and/or resilience of Rocky Littoral molluscs to stock depletion by the indigenous coastal people of Transkei, Southern Africa," Biological Conservation, vol. 56, no. 3, pp. 245-264, 1991. 
[59] T. Lasiak, "Spatial variation in density and biomass of patellid limpets inside and outside a marine protected area," Journal of Molluscan Studies, vol. 72, no. 2, pp. 137-142, 2006.

[60] B. Gohil and R. Kundu, "Ecological status of Cellana radiata at Dwarka Coast, Gujarat, India," Research Journal of Recent Sciences, vol. 2, pp. 1-5, 2013.

[61] B. Gohil and R. Kundu, "Ecological status of Cerethium caeruleum at Dwarka coast, Gujarat (India)," Indian Journal of Geo-Marine Science, vol. 42, pp. 481-486, 2013.

[62] M. N. Prasad and A. P. Mansuri, "Population density of the Limpet, Cellana radiata (Born) in polluted waters at Porbandar, West coast of India," Indian Journal of Marine Science, vol. 11, pp. 180-181, 1982. 

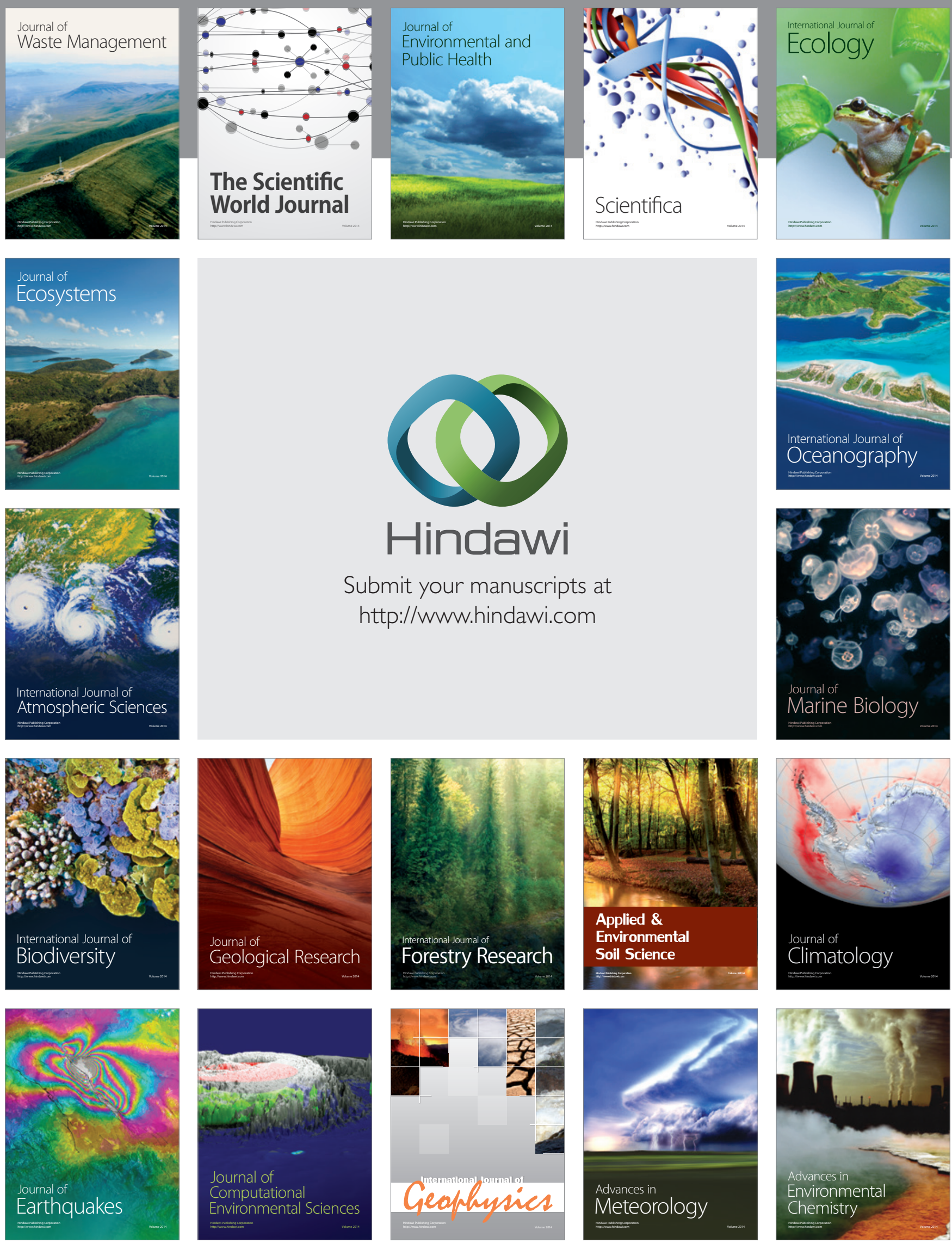